\title{
PERBEDAAN PRESTASI BELAJAR FISIKA ANTARA PESERTA DIDIK YANG DIAJAR DENGAN METODE LEVELS OF INQUIRY LEARNING CYCLE DAN METODE CERAMAH
}

\author{
Nobita Triwijayanti \\ Alumni Program Pascasarjana Magister Manajemen Pendidikan \\ FKIP Universitas Kristen Satya Wacana \\ Nobitatri@yahoo.com \\ J.T. Lobby Loekmono \\ Program Pascasarjana Magister Manajemen Pendidikan \\ FKIP Universitas Kristen Satya Wacana \\ lloekmono@yahoo.com \\ Sutriyono \\ Program Pascasarjana Magister Manajemen Pendidikan \\ FKIP Universitas Kristen Satya Wacana \\ sutriyono@staff.uksw.edu
}

\begin{abstract}
Type of this research is experiment research which has a purpose to know the diffrence of phisics study achievement among students taught with levels of inquiry learning cycle method and students taught with direct teaching method. The participants were 46 students from XI SMK official school, Landak District, West Kalimantan. The data were taken by using $t$ test and the result shows there is significant difference between students taught with levels of inquiry learning cycle method and students taught with direct teaching method. The students score average of inquiry learning cycle method is better than the students score of direct teaching method.
\end{abstract}

Key words: Levels of Inquiry Learning Cycle Method, Direct Teaching Method, Phisics Study Achievement. 


\section{PENDAHULUAN}

Dalam Majalah Ilmu Pengetahuan Alam Vol.VII 2007, dituliskan bahwa pada pelajaran sains terutama Fisika, hasil pembelajaran peserta didik masih sangat rendah terlihat dari hasil UN peserta didik SMA, SMK dan SMP, serta hasil tes PISA (Programme for International Student Assessment) 2003, menunjukkan siswa kita menduduki urutan ke 39 dari 41 negara peserta (Darliana 2007: 19). Selanjutnya Efendi (2010) menyatakan bahwa rendahnya prestasi peserta didik Indonesia dalam tes PISA 2009, TIMSS 1999, TIMSS 2003, TIMSS 2007 di bidang sains dan matematika menunjukkan bahwa sebagian besar peserta didik Indonesia belum dapat memenuhi kompetensi mata pelajaran Fisika. Dimana hasil tes PISA (Programme for International Student Assessment) 2009 yang menunjukkan bahwa peserta didik Indonesia menduduki peringkat 10 besar terbawah dari 65 negara di dunia yang menjadi peserta PISA. Adapun kriteria pengukuran PISA mencakup kemampuan kognitif (knowladge) dan juga keahlian peserta didik berusia 15 tahun pada bidang membaca (reading), matematika, dan kemampuan sains (scientific literacy). Pada bidang membaca peserta didik Indonesia mendapatkan peringkat 57 , pada bidang matematika mendapatkan peringkat 61 dan pada bidang sains mendapatkan peringkat 60 dari 65 negara peserta (OECD PISA, 2009). Hal ini dapat dilihat pada Ranking by Mean Score for Reading, Mathematics and Science (lampiran 1) (PISA, 2009). Hasil serupa juga ditunjukkan oleh hasil TIMSS (Trends in Mathematics and Science Study) yang diadakan pada tahun 1999, 2003 dan 2007. TIMSS merupakan studi internasional tentang prestasi peserta didik kelas VIII dalam memahami teori maupun penerapan dalam bidang matematika dan sains. Pada tahun 1999 dalam bidang matematika, peserta didik Indonesia mendapatkan peringkat 34 dari 38 negara, di tahun 2003 mendapat peringkat 35 dari 46 negara dan tahun 2007 mendapatkan peringkat 36 dari 49 negara peserta TIMSS. Dalam bidang sains, di tahun 1999 peserta didik Indonesia menempati peringkat 32 dari 38 negara, tahun 2003 menempati peringkat 37 dari 46 negara dan tahun 2007 menempati peringkat 35 dari 49 negara peserta TIMSS (lampiran 3) (Puspendik, 2011). Mata pelajaran Fisika yang merupakan salah satu ilmu dalam bidang sains yang mempelajari alam sekitar secara sistematik.Dalam mata pelajaran Fisika tidak hanya dapat dipelajari melalui pemahan konsep-konsep saja, namun juga harus dilengkapi dengan kemampuan matematis. Sehingga rendahnya prestasi peserta didik Indonesia dalam tes PISA 2003, PISA 2009, TIMSS 1999, TIMSS 2003, TIMSS 2007 menunjukkan ketidakmampuan peserta didik dalam mengintegrasikan konsep Fisika yang telah mereka pelajari. Rendahnya prestasi belajar peserta didik salah satunya disebabkan karena kurangnya pengalaman menggunakan labotarium yang bersifat inkuiri (penyelidikan) sehingga peserta didik mengalami miskonsepsi tentang konsep Fisika dan berujung pada ketidakmampuan peserta didik dalam menerapkan konsep Fisika secara matematis serta dalam kehidupan sehari-hari.

Dari hasil wawancara dengan tujuh guru Fisika baik pada tingkat SMA/SMK maupun SMP di sekitar Salatiga dan kabupaten Semarang, diperoleh informasi bahwa peserta didik cenderung menghafalkan rumus (persamaan) yang berlaku dalam pelajaran Fisika tapi kurang memahami konsep yang mendasarinya. Hal ini terbukti ketika peserta didik diberi soal cerita yang dikembangkan (problem solving), mereka akan merasa kesulitan dalam 
mengerjakan soal tersebut sesuai dengan konsep yang ada. Selain itu, dalam kegiatan praktikum peserta didik SMK cenderung hanya meniru atau mengikuti arahan dari guru dan kurang mampu mengintegrasikan konsepkonsep Fisika yang mereka pelajari dengan aplikasi atau terapan dari konsep Fisika tersebut. Hal ini terbukti ketika mereka harus merakit sebuah alat tanpa ada arahan dari sang guru, mereka akan merasa kesulitan dalam merakit alat sesuai dengan konsep yang ada. Terlebih lagi ketika peserta didik harus menghadapi ujian praktik di sekolah, tampak sekali bahwa peserta didik mengalami kesulitan dalam menjelaskan konsep-konsep Fisika yang menjadi dasar dari perakitan alat yang mereka rakit, walaupun mereka dapat merakit alat tersebut dengan benar. Hal ini terbukti dari 30 peserta didik dari salah satu SMK di Salatiga hanya ada 3 peserta didik yang mendapat nilai penuh dalam aspek pemahaman materi yang diujikan dan dalam aspek merangkai alat tidak ada peserta didik yang dapat mencapai nilai penuh (Lampiran 4). Keadaan ini, menunjukkan bahwa kompetensi dasar agar peserta didik memahami konsep dan mampu mengintegrasikannya dengan kehidupan sehari-hari belum tercapai.

Pada penelitian ini, peneliti memilih peserta didik di SMK Negeri 1 Ngabang, Kabupaten Landak sebagai subyek penelitian.Hal ini dikarenakan peserta didik di SMK Negeri 1 Ngabang juga mengalami kesulitan dalam memahami dan mempelajari materi mata pelajaran Fisika. Kecenderungan peserta didik untuk menghafalkan rumus (persamaan) dan kurang memahami konsep materi Fisika membuat peserta didik kesulitan untuk mengerjakan soal yang berbasis pada sebuah fenomena atau biasa disebut dengan soal cerita (Problem solving) ketika menghadapi tes tertulis. Hal ini dapat dibuktikan melalui Nilai Laporan Hasil
Belajar (LHB) SMK Negeri 1 Ngabang pada Semester Genap Tahun Pelajaran 2011/2012 yang menunjukkan bahwa $20 \%$ peserta didik kelas X jurusan Teknik Kendaraan Ringan belum mampu mencapai nilai KKM mata pelajaran Fisika, dari total 25 peserta didik terdapat 5 peserta didik yang belum tuntas KKM. Adapun nilai KKM mata pelajaran Fisika kelas X jurusan Teknik Kendaraan Ringan di SMK Negeri 1 Ngabang adalah 65, nilai KKM ini cenderung rendah karena di bawah target KKM secara Lokal Sekolah adalah 70 .

Sumber permasalahan yang sesungguhnya adalah kesalahan guru dalam menerapkan manajemen pembelajaran di kelas. Penggunaan metode pembelajaran yang kurang tepat, pembelajaran yang tidak bervariasi dan bersifat teacher centered menyebabkan peserta didik berkembang sebagai pelajar yang pasif serta tidak dapat mengembangkan kemampuan atau pengetahuan yang ada pada dirinya (Nurinasari, 2004). Padahal diketahui dengan adanya lingkungan belajar yang kondusif, peserta didik dapat mengembangkan keterampilan dan pemahaman yang lebih baik mengenai pengetahuan yang mereka terima. Lingkungan belajar yang dimaksudkan disini harus mencakup proses belajar-mengajar yang merupakan perwujudan konkrit dari pengolahan informasi yang memberikan makna pada semua kesan sensoris (Winkel 2007, 349).

Berdasarkan permasalahan yang sering dihadapi di lapangan maka setiap guru perlu merancang suatu kegiatan pembelajaran yang berpusat pada peserta didik serta dapat mendorong peserta didik untuk belajar secara aktif dalam mengembangkan pengetahuan dan keterampilannya. Perkembangan pengetahuan dan kemampuan berpikir peserta didik dapat terjadi ketika ada orang lain yang memberikan sedikit petunjuk dan menantang mereka untuk 
mengubah cara berpikirnya (Winkel 2007,21). Salah satu cara adalah dengan menciptakan suasana pembelajaran yang aktif, yaitu melalui penerapan metode pembelajaran Learning Cycle yang berbasis pada inkuiri (penyelidikan).

Levels of Inquiry Learning Cycle merupakan perkembangan terbaru dari metode Learning Cycle yang berbasis pada inkuiri. Metode ini dikembangkan oleh Carl J. Wenning di Illinois State University, Physics Teacher Education Program, USA. Levels of Inquiry Learning Cycle adalah suatu model pembelajaran yang berpusat pada peserta didik (student centered) yang mana siklus pembelajaran berlangsung melalui 5 tahap yaitu Observation, Manipulation, Generation, Verification dan Application (Wenning, 2011). Siklus tersebut kemudian diterapkan pada Levels of Inquiry yang terdiri dari Discovery Learning (Pembelajaran Discovery), Interactive Demonstration (Demonstrasi Interaktif), Inquiry Lesson (Pelajaran Inkuiri), Inquiry Lab (Laboratorium Inkuiri) dan Hypothetical Inquiry (Inkuiri Hipotesis) (Wenning, 2005a). Melalui tahapan-tahapan ini diharapkan peserta didik berperan secara aktif mengembangkan kemampuan berpikirdan menerapkan pengetahuan untuk mencapai kompetensi yang menjadi kompetensi dasarnya.

Hasil penelitian Budiarsih dan Widarti (2004) dalam Fajaroh \& Dasna (2007) mengenai implementasi Learning Cycle di perguruan tinggi dan sekolah menengah atas menunjukkan bahwa model Learning Cycle dapat meningkatkan kualitas proses dan hasil belajar peserta didik secara signifikan. Demikian juga dengan hasil PTK yang dilakukan oleh Fibriyanti (2006) terhadap peserta didik VII-B SMP Laboratorium UM Semester I Tahun ajaran 2006/2007 menunjukkan bahwa Learning Cycle dapat meningkatkan prestasi belajar peserta didik walaupun masih dalam skala yang cukup kecil.
Penelitian oleh Ates (2005) mengenai pengaruh Learning Cycle yang berbasis inkuiri pada mahasiswa di Abant Izzet Baysal University, Golkoy-Bolu, Turkey menunjukkan bahwa Learning Cycle yang berbasis pada inkuiri tidak mampu untuk meningkatkan prestasi belajar peserta didik secara signifikan. Terutama pada pemahaman yang bersifat mikroskopis seperti pada materi rangkaian listrik. Ates beranggapan bahwa pada materi yang bersifat mikroskopis, aplikasi model pembelajaran Learning Cycle yang berbasis inkuiri akan menimbulkan miskonsepsi pada peserta didik karena tidak dapat dilihat secara langsung.

Mengamati beberapa hasil penelitian sebelumnya maka peneliti tertarik melakukan penelitian untuk mengetahui hasil prestasi belajar Fisika peserta didik melalui aplikasi model pembelajaran Learning Cycle yang berbasis inkuiri yaitu metode pembelajaran Levels of Inquiry Learning Cycle. Pada penelitian ini, peneliti memilih materi yang bersifat mikroskopis yaitu rangkaian listrik, dimana pada penelitian sebelumnya peneliti telah mengaplikasikan Spectrum Inquiry (Wenning, 2005b) yang merupakan bagian dari Levels of Inquiry Learning Cycle pada materi yang bersifat konkrit yaitu hukum Hooke. Hasil dari penelitian sebelumnya menemukan bahwa aplikasi dari Spectrum Inquiry pada materi hukum Hooke dapat meningkatkan prestasi belajar pada peserta didik SMA (Triwijayanti, 2011). Alasan lain yang mendasari peneliti memilih materi yang bersifat mikriskopis adalah hasil penelitian yang dilakukan Ates (2005) yang mengatakan bahwa Learning Cycle yang berbasis inkuiri tidak mampu meningkatkan pemahaman peserta didik pada materi yang bersifat mikroskopis.

Pada penelitian ini peneliti memilihjenis penelitian eksperimen maka akan ada kelas 
eksperimen dan kelas kontrol. Pada kelas eksperimen, peserta didik akan diajar dengan menggunakan metode pembelajaran Levels of Inquiry Learning Cycle dan pada kelas kontrol, peserta didik akan diajar dengan menggunakan model pembelajaran tradisioanal yaitu metode Ceramah. Adapun tempat pelaksanaan penelitian ini adalah SMK Negeri 1 Ngabang, Kabupaten Landak, dimana sampel dari penelitian ini adalah peserta didik kelas XI jurusan Teknik Kendaraan Ringan dan jurusan Teknik Sepeda Motor.

Berdasarkan uraian pada paragraf sebelumnya maka peneliti akan melaksanakan penelitian eksperimen untuk mengetahui signifikansi perbedaan prestasi belajar Fisika peserta didik yang diajar menggunakan metode pembelajaran Levels of Inquiry Learning Cycle dengan peserta didik yang diajar dengan metode Ceramah pada materi rangkaian listrik di kelas XI jurusan Teknik Kendaraan Ringan SMK Negeri 1 Ngabang, Kabupaten Landak.

Sejalan dengan latar belakang di atas maka masalah dalam penelitian ini dirumuskan sebagai "Adakah perbedaan signifikan prestasi belajar Fisika peserta didik yang diajar menggunakan metode pembelajaran Levels of Inquiry Learning Cycle di kelas XI jurusan Teknik Kendaraan Ringan dengan peserta didik yang diajar menggunakan metode Ceramah pada materi rangkaian listrik di kelas XI jurusan Teknik Sepeda Motor SMK Negeri 1 Ngabang, Kabupaten Landak?" Sedang tujuan penelitian ini adalah untuk mengetahui signifikansi perbedaan prestasi belajar Fisika pada peserta didik yang diajar menggunakan metode pembelajaran Levels of Inquiry Learning Cycle di kelas XI jurusan Teknik Kendaraan Ringan dengan peserta didik yang diajar menggunakan metode Ceramah pada materi rangkaian listrik di kelas XI jurusan Teknik
Sepeda Motor SMK Negri 1 Ngabang Kabupaten Landak.

\section{METODE}

Jenis penelitian yang digunakan dalam penelitian ini adalah penelitian eksperimental. Pada penelitian ini akan ada kelompok eksperimen dan kelompok kontrol sebagai pembanding. kelompok eksperimen akan diajar dengan menggunakan metode pembelajaran Levels of Inquiry Learning Cycle dan pada kelompok kontrol akan diajar dengan menggunakan metode Ceramah. Penelitian ini akan dilaksanakan pada SMK Negeri 1 Ngabang, Kabupaten Landak Kalimantan Barat. Dalam penelitian ini kelompok eksperimen adalah peserta didik kelas XI Jurusan Teknik Kendaraan Ringan SMK Negeri 1 Ngabang dan kelompok kontrol adalah peserta didik kelas XI Teknik Sepeda Motor SMK Negeri 1 Ngabang. Sedang subyek dari penelitian ini adalah 25 orang peserta didik kelas XI Jurusan Teknik Kendaraan Ringan dan 21 orang peserta didik kelas XI Jurusan Teknik Sepeda Motor di SMK Negeri 1 Ngabang, Kabupaten Landak. Peserta didik kelas XI Jurusan Teknik Kendaraan Ringan merupakan kelompok eksperimen dan peserta didik kelas XITeknik Sepeda Motor merupakan kelompok kontrol.

Variabel penelitian terdiri dari: 1) variabel perlakuan yaitu jenis metode pembelajaran Levels of Inquiry Learning Cycle dan metode Ceramah sebagai variabel bebas, dan 2) prestasi belajar Fisika sebagai variabel terikat.

Dalam penelitian ini digunakan dua kelas paralel pada mata pelajaran dan topik yang sama. Salah satu kelas menjadi kelompok kontrol yaitu kelas yang menggunakan metode Ceramah.Sedangkan kelas lainnya menjadi kelompok eksperimen yang menggunakan metode pembelajaran Levels of Inquiry Learning 
Cycle. Sebelum melakukan penelitian, peneliti akan merancang rencana pelaksanaan pembelajaran (RPP) untuk kelas eksperimen maupun kelas kontrol. Setelah ini peneliti akan membuat serangkaian soal untuk Pretest dan Posttest. Pada tahap awal, kedua kelas diberikan Pretest guna mengukur kemampuan peserta didik sebelum diberikan perlakuan. Setelah itu kedua kelas diberikan perlakuan yang berbeda. Kelompok eksperimen dengan menggunakan metode Levels of Inquiry Learning Cycle dan pada kelompok kontrol menggunakan metode Ceramah. Pada akhir pembelajaran peserta didik diberikan Posttest untuk mengevaluasi hasil belajar tentang materi yang telah dipelajari.Kemudian peneliti membandingkan hasil Posttest peserta didik di kelas ekperimen dangan Posttest peserta didik di kelas kontrol.

Berikut ini adalah desain penelitian:

Tabel 1 Desain Penelitian

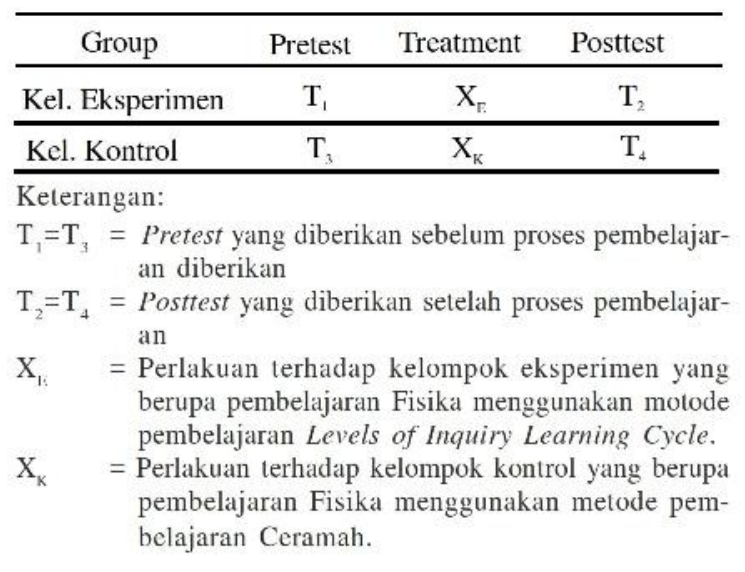

Pada penelitian ini instrumen penelitian yang digunakan untuk mengukur prestasi belajar Fisika adalah tes prestasi belajar. Tes prestasi disusun berdasarkan kompetensi dasar tentang hubungan antara tegangan, hambatan, dan arus listrik. Materi pembelajaran yang diberikan sesuai dengan kurikulum yang berlaku di SMK Negeri 1 Ngabang yaitu Kurikulum Tingkat Satuan Pendidikan (KTSP).Pengukuran tes prestasi menggunakan pengukuran kognitif dan praktik (performance assessment). Sedangkan soal pilihan ganda yang diberikan pada saat pretest sama dengan soal yang diberikan pada saat posttest, namun pada soal posttestakan ditambahkan soal praktik (uraian) yang berdasarkan problem solving dimana praktik peserta didik dalam proses penyelesaian soal akan di nilai dengan pengukuran praktik (performance assessment).

Teknik analisis data yang digunakan dalam penelitian ini adalah metode analisis instrumen deskriptif yang bertujuan memberikan gambaran terhadap data-data pada variabel penelitian yang digunakan dalam penelitian dan metode analisis inferensial yang bertujuan untuk menguji hipotesis, ada tidaknya berbedaan yang signifikan antara implementasi metode pembelajaran Levels of Inquiry Learning Cycle pada kelas XI jurusan Teknik Kendaraan Ringan dan metode pembelajaran Ceramah pada kelas XI jurusan Teknik Kendaraan Teknik Sepeda Motordi SMK Negeri 1 Ngabang, berdasarkan persyaratan instrumen yaitu uji homogenesitas, dilanjutkan dengan uji beda independent sample $T$ test dengan menggunakan program SPSS 20.

Instrumen yang baik harus memenuhi dua persyaratan utama yaitu valid dan reliable (Arikunto 2006, 168). Suatu alat ukur dikatakan valid jika alat itu mengukur apa yang harus diukur oleh alat itu dan reliabel jika secara konsisten memberikan hasil pengukuran yang sama pada beberapa kali pengujian (Nasution 2007,350). Instrumen dikatakan valid apabila instrumen tersebut dapat dengan tepat mengukur apa yang akan diukur. Dengan kata lain validitas berkaitan dengan "ketepatan" alat ukur. Instrumen yang valid akan menghasilkan data yang valid juga (Widoyoko 2012, 134). Menurut Sugiono $(2007,350)$, validitas dalam 
model pembelajaran harus memenuhi dua hal validitas isi dan validitas konstruk.

Validitas isi sering disebut juga validitas kurikuler. Validitas ini erat kaitanya dengan materi yang akan diukur dalam instrumen. Validasi isi mencerminkan sejauh mana butirbutir dalam tes mencerminkan materi yang disajikan dalam kurikulum.Sebuah instrumen dikatakan memiliki validitas ini jika butir-butir tes bersifat representative terhadap ini materi dalam kurikulum. Validitas konstruk adalah validitas yang menyangkut bangunan teoritik variabel yang akan diukur. Sebuah instrumen dikatakan mempunyai validitas konstruk apabila butir-butir soal yang disusun dalam tes mengukur setiap aspek berpikir dari sebuah variabel yang akan diukur melalui instrumen tersebut (Widoyoko 2012, 140).

Untuk validitasi dan validitas konstruk, penelitian ini menggunakan pendapat dari para pakar di bidang Fisika.Adapun instrumen yang divalidasi oleh para pakar adalah soal pretest dan posttest. Instrumen pada penelitian ini akan divalidasi item untuk mengetahui nilai validitas setiap item pada instrumen. Dalam uji validitas item penelitian ini, nilai corrected item-total correlationakan dibandingkan dengan nilai $\mathrm{r}_{x y}$ kritik. Adapun nilai $r$ kritik validitas item intrumen adalah 0,3. Menurut Widoyoko $(2012,143)$, sebuah item soal dikatakan valid apabila nilai $r_{x y}$ lebih besar sama dengan 0,3 $\left(r_{x y} e " 0,3\right)$ maka item tersebut valid. Sebaliknya apabila nilai $r_{x y}$ lebih kecil dari $0,3\left(r_{x y}<0,3\right)$ maka item tersebut tidak valid.

Soal pretest dan posttest yang telah di validasi kemudian diuji cobakan (tryout) kepada siswa yang sudah mempelajari materi tersebut. Dari hasil uji coba tersebut akan dilakukan pengujian reliabilitas dengan menggunakan reliabilitas. Menurut Widoyoko (2012) reliabilitas internal diperoleh dengan menganalisis data dari satu kali pengumpulan
data.Metode analisis reliabilitas internal yang digunakan adalah instrumen skor diskrit dan skor non diskrit. Instrumen skor diskrit digunakan untuk jenis soal pilihan ganda dan menjodohkan, sedangkan untuk jenis soal essay pada soal praktik menggunakan instrumen skor non diskrit. Dalam penelitian, untuk mencari tingkat reliabilitas instrumen yang skornya diskrit ( 1 dan 0 ) menggunakan metode belah dua (split-halfmetode) yang dikemukakan oleh Spearman-Brown. Menurut Widoyoko (2012) cara membelah butir instrumen, yaitu dengan membagi butiran instrumen menjadi kelompok butiran awal dan butiran akhir. Separuh jumlah pada nomor-nomor awal disebut belahan awal dan separuh jumlah pada nomor-nomor akhir disebut belahan akhir.

Untuk mencari korelasi antara belahan awal (X) dan belahan akhir (Y) penelitian ini menggunakan korelasi product moment dan untuk memperoleh indeks reliabilitas instrumen penelitian ini menggunakan rumus SpearmanBrown (Widoyoko, 2012). Dari hasil perhitungan tersebut, instrumen dikatakan reliabel apabila $r_{\text {hitung }}$ lebih besar dari $r_{\text {tabel }}$ $\left(\mathrm{r}_{\mathrm{h}} \mathrm{e}\right.$ " $\left.\mathrm{r}_{\mathrm{t}}\right)$, dimana $\mathrm{r}_{\text {tabel }}$ didapat dari tabel $\mathrm{r}$ product moment dengan jumlah $\mathrm{N}$ yang sama pada taraf signifikasi 5\%. Sebaliknya intrumen dikatakan tidak reliabel apabila $r_{\text {hitung }}$ lebih kecil dari $\mathrm{r}_{\text {tabcl }}\left(\mathrm{r}_{\mathrm{h}}<\mathrm{r}_{\mathrm{L}}\right)($ Widoyoko, 2012).

Instrumen skor non diskrit adalah instrumen pengukuran yang dalam sistem scoring bukan 1 (satu) dan 0 (nol), tetapi bersifat gradual, yaitu ada penjenjangan skor mulai dari skor tertinggi sampai skor terendah.Instrumen skor non diskrit ini digunakan untuk instrumen posttest yang berbentuk uraian. Interval skor yang digunakan adalah 1 (satu) sampai 10 (sepuluh).Pada instrumen skor non diskrit analisis reliabilitasnya menggunakan rumus Alpha (Widoyoko, 2012). 
Dari hasil perhitungan, instrumen dikatakan reliabel apabila nilai koefisien Alpha lebih besar dari harga kritik atau standar reliabilitas. Harga kritik untuk indeks reliabilitas intrumen adalah 0,7. Artinya apabila nilai koefisien Alpha lebih besar dari 0,7 maka intrumen tersebut reliabel dan sebaliknya bila nilai koefisien Alpha lebih rendah dari 0,7 maka instrumen tersebut tidak reliabel (Widoyoko, 2012).

\section{HASIL DAN PEMBAHASAN}

\section{Analisis saat Pretest}

Pretest diberikan pada sampel untuk mengetahui kemampuan awal peserta didik di kelompok eksperimen dan kelompok kontrol. Selanjutnya kedua kelompok tersebut diberikan perlakuan yang berbeda, pada kelompok kontrol akan diberikan pembelajaran dengan metode Ceramah dan pada kelompok eksperimen diberikan pembelajaran dengan metode Levels of Inquiry Learning Cycle.
Hasil Descriptive Statistics dari Pretest dapat dilihat pada tabel 2.

Pada Tabel 2 menunjukkan rata-rata pretest kelas XITKR sebesar 60,08 dan ratarata pretest kelas XITSM sebesar 60,19. Nilai maksimum kelas XI TKR adalah 75 dan nilai maksimum kelas XI TSM adalah 72.Sedang nilai minimum untuknilai kelas XITKR adalah 43 dan dikelas XI TSM adalah 45.

Pada kelas eksperimen maupun kelas kontrol, uji beda pada pretest yang dilakukan dengan menggunakan uji independent sample t-test serta bentuk dan jumlah soal yang sama. Hal ini bertujuan untuk mengetahui kemampuan awal dan homogenitasnya. Hasil uji beda pretest pada kelas eksperimen dan kontrol dapat dilihat pada Tabel 3.

Dari Tabel 3 diketahui hasil $\mathrm{F}_{\text {hitung }}$ levene test sebesar 0,077 dengan signifikansi 0,782 lebih besar dari 0,05 , maka $\mathrm{H}_{0}$ diterima atau kedua populasi memiliki varian yang sama. Dengan kata lain kedua kelas homogen. Analisis uji beda independent sample t-test terlihat

Tabel 2 Hasil Descriptive Statistics dari Pretest Kelas XI TKR dan Kelas XI TSM

Descriptive Statistics

\begin{tabular}{lcccccccc}
\hline & N & Range & Minimum & Maximum & \multicolumn{2}{c}{ Mean } & $\begin{array}{l}\text { Std. } \\
\text { Deviation }\end{array}$ & Variance \\
\hline & Statistic & Statistic & Statistic & Statistic & Statistic & Std. Error & Statistic & Statistic \\
\hline XI.TKR & 25 & 32.00 & 43.00 & 75.00 & 60.0800 & 1.43634 & 7.18169 & 51.577 \\
XI.TSM & 21 & 27.00 & 45.00 & 72.00 & 60.1905 & 1.47296 & 6.74996 & 45.562 \\
$\begin{array}{l}\text { Valid N } \\
\text { (listwise) }\end{array}$ & 21 & & & & & & & \\
\hline
\end{tabular}

Tabel 3 Hasil Uji Beda Pretest Kelas XI TKR dan Kelas XI TSM

Independent Samples Test

\begin{tabular}{|c|c|c|c|c|c|c|c|c|c|c|}
\hline & & \multicolumn{2}{|c|}{$\begin{array}{l}\text { Levene's } \\
\text { Test for } \\
\text { Equality of } \\
\text { Variances }\end{array}$} & \multicolumn{5}{|c|}{ I test for Equality of Means } & & \\
\hline & & \multirow[t]{2}{*}{$\mathrm{F}$} & \multirow[t]{2}{*}{ Sig. } & \multirow[t]{2}{*}{$\mathrm{T}$} & \multirow[t]{2}{*}{ df } & \multirow{2}{*}{$\begin{array}{l}\text { Sig. } \\
(2- \\
\text { tailed })\end{array}$} & \multirow[t]{2}{*}{$\begin{array}{l}\text { Mean } \\
\text { Difference }\end{array}$} & \multirow[t]{2}{*}{$\begin{array}{l}\text { Std. Error } \\
\text { Difference }\end{array}$} & \multicolumn{2}{|c|}{$\begin{array}{l}95 \% \text { Confidence } \\
\text { Interval of the } \\
\text { Difference }\end{array}$} \\
\hline & & & & & & & & & Lower & Upper \\
\hline \multirow[t]{2}{*}{ Pretest } & $\begin{array}{l}\text { Equal } \\
\text { variances } \\
\text { assumed }\end{array}$ & .077 & .782 & -.053 & 44 & .958 & -.11048 & 2.06871 & -4.27968 & 4.05873 \\
\hline & $\begin{array}{l}\text { Equal } \\
\text { variances } \\
\text { not assumed }\end{array}$ & & & -.054 & 43.410 & .957 & -.11048 & 2.05735 & -4.25838 & 4.03743 \\
\hline
\end{tabular}


bahwa $t_{\text {hitung }}$ di bagian equal variance assumed adalah - 0,053 dengan signifikansi (2tailed) sebesar 0,958. Karena $\mathrm{p}>0,05$ maka dapat disimpulkan tidak terdapat perbedaan nilai hasil pretest dari kelas eksperimen dan kelas kontrol. Dengan demikian eksperimen dapat dilanjutkan dengan menggunakan kedua kelas tersebut (XI-TKR dan XI-TSM).

\section{Analisis saat Posttest}

Perhitungan uji beda rata-rata posttest dari kelas eksperimen dan kontrol dilakukan dengan menggunakan independent sample ttest bertujuan untuk melihat perbedaan prestasi belajar peserta didik yang diajar dengan metode Levels of Inquiry Learning Cycle dan peserta didik yang diajar dengan menggunakan metode Ceramah. Pada tahap posttest peserta didik akan diberikan dua jenis soal yang berbeda, yaitu soal pilihan ganda dan soal uraian berupa problem solving. Dari posttest dengan soal pilihan ganda akan didapatkan nilai pengetahuan dengan pengukuran kognitif sedangkan dari soal uraian yang berupa problem solving akan didapatkan nilai pengetahuan dan praktik peserta didik. Hasil rata-rata nilai pengetahuan posttest disajikan pada Tabel 4.

Dimana pada Tabel 4 diketahui nilai rata-rata posttest dari kelas eksperimen (XITKR) lebih tinggi daripada nilai rata-rata posttest dari kelas kontrol (XI-TSM). Pada Posttest $_{\text {soal } P G}$ nilai rata-rata kelas XI-TKR adalah 91,6 sedangkan nilai rata-rata kelas XITSM adalah 60,24 dan pada Posttest soal ur $_{\text {nilai }}$ rata-rata kelas XI-TKR adalah 94 sedangkan nilai rata-rata kelas XI-TSM adalah 57,29.

Tabel 4 Hasil Rata-rata Nilai Pengetahuan Prestasi Belajar KelasXI-TKR dan

Kelas XI-TSM

\begin{tabular}{llllll} 
Group Statistics & (Posttest \\
\hline & Kelaal PG & dan Posttest & \\
stal uraian & \\
\hline Posttest.PG & N & Mean & Std. Deviation & Std. Error Mean \\
\hline & Eksperimen & 25 & 91.6000 & 6.12372 & 1.22474 \\
& Kontrol & 21 & 60.2381 & 4.66803 & 1.01865 \\
\hline Posttest.Ur & Eksperimen & 25 & 94.0000 & 5.14782 & 1.02956 \\
& Kontrol & 21 & 57.2857 & 2.95200 & .64418 \\
\hline
\end{tabular}

Tabel 5 HasilUji Beda Rata-rata Nilai Pengetahuan Prestasi Belajar KelasXI-TKRdan Kelas XI-TSM

Independent Samples Test (Posttest ${ }_{\text {scoul PG }}$ dan Posttest scal uraian $)$

\begin{tabular}{|c|c|c|c|c|c|c|c|c|c|c|}
\hline & & \multicolumn{2}{|c|}{$\begin{array}{l}\text { Levene's } \\
\text { Test for } \\
\text { Equality of } \\
\text { Variances } \\
\end{array}$} & \multicolumn{5}{|c|}{ test for Equality of Means } & & \\
\hline & & F & Sig. & $\mathrm{T}$ & Df & $\begin{array}{l}\text { Sig(2- } \\
\text { tailed) }\end{array}$ & Mean & Std. Error & \multicolumn{2}{|c|}{$\begin{array}{l}95 \% \text { Confidence } \\
\text { Interval of the } \\
\text { Difference }\end{array}$} \\
\hline & & & & & & & Difference & Difference & Lower & Upper \\
\hline \multirow[t]{2}{*}{ Posttest.PG } & $\begin{array}{l}\text { Equal } \\
\text { variances } \\
\text { assumed }\end{array}$ & 4.847 & .033 & 19.229 & 44 & .000 & 31.36190 & 1.63097 & 28.07491 & 34.64890 \\
\hline & $\begin{array}{l}\text { Equal } \\
\text { variances } \\
\text { not } \\
\text { assumed } \\
\end{array}$ & & & 19.687 & 43.633 & .000 & 31.36190 & 1.59300 & 28.15067 & 34.57314 \\
\hline \multirow[t]{2}{*}{ Posttest.Ur } & $\begin{array}{l}\text { Equal } \\
\text { variances } \\
\text { assumed }\end{array}$ & 14.171 & .000 & 28.903 & 44 & .000 & 36.71429 & 1.27026 & 34.15425 & 39.27432 \\
\hline & $\begin{array}{l}\text { Equal } \\
\text { variances } \\
\text { not } \\
\text { assumed }\end{array}$ & & & 30.230 & 39.251 & .000 & 36.71429 & 1.21448 & 34.25827 & 39.17031 \\
\hline
\end{tabular}


Berdasarkan Tabel 5 hasil Posttest ${ }_{\text {soal }}$ PG diketahui hasil $\mathrm{F}_{\text {hitung }}$ levene test sebesar 4,847 dengan signifikansi 0,033. Karena $\mathrm{p}<0,05$, maka kedua populasi tersebut mempunyai variance yang berbeda. Analisis uji bedat-test terlihat bahwa nilai $t_{\text {hitung }}$ dibagian equal assumed adalah 19,229 dengan signifikansi (2-tailed) sebesar 0,000. Karena $\mathrm{p}<0,05$, maka $\mathrm{H}_{0}$ ditolak dan $\mathrm{H}_{1}$ diterima yang artinya bahwa ada perbedaan prestasi belajar Fisika antara peserta didik yang diajar dengan menggunakan metode Levels of Inquiry LearningCycle dengan peserta didik yang diajar dengan menggunakan metode Ceramah.

Sedangkan hasil Posttest $_{\text {soal Ur }}$, diketahui hasil $\mathrm{F}_{\text {hitung }}$ levene test sebesar 14,171 dengan signifikansi sebesar 0,000. Karena $\mathrm{p}<0,05$, maka kedua populasi tersebut memiliki variance yang berbeda. Analisis uji bedat-test terlihat bahwa nilai $\mathrm{t}_{\text {hitung }}$ di bagian equal assumedadalah 28,903 dengan signifikansi sebesar 0,000. Karena $\mathrm{p}<0,05$, maka $\mathrm{H}_{0}$ ditolak dan $\mathrm{H}_{1}$ diterima artinya bahwa ada perbedaan prestasi belajar Fisika peserta antara peserta didik yang diajar dengan menggunakan metode Levels of Inquiry LearningCycle dengan peserta didik yang diajar dengan menggunakan metode Ceramah.

Berikut ini adalah hasil perhitungan uji beda rata-rata nilai praktik dengan performance assessmentpada peserta didik yang diajar dengan menggunakan metode Levels of Inquiry Learning Cycle dan peserta didik yang diajar dengan metode Ceramah.

Berdasarkan tabel 6 diketahui nilai rata-rata posttest ${ }_{\text {praktik }}$ dari kelas eksperimen (XI-TKR) lebih tinggi daripada nilai rata-rata posttest $_{\text {praktik }}$ dari kelas kontrol (XI-TSM).

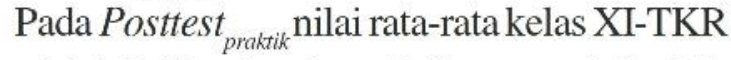
adalah 9,52 sedangkan nilai rata-rata kelas XITSM adalah 5,95.

Tabel 6 Hasil Rata-rata Nilai Praktik Prestasi Belajar Fisika antara kelasXI-TKRdan kelas XI-TSM

Group Statistics

\begin{tabular}{llllll}
\hline & Kelas & $\mathrm{N}$ & Mean & Std. Deviation & Std. Error Mean \\
\hline Posttest_- Eksperimen & 25 & 9.5160 & .37603 & .07521 \\
Praktik & Kontrol & 21 & 5.9524 & .60961 & .13303 \\
\hline
\end{tabular}

Tabel 7 Hasil Uji Beda Rata-rata Nilai Praktik Prestasi Belajar Fisika antara kelas XI-TKR dan kelas XI-TSM

Independent Samples Test

\begin{tabular}{|c|c|c|c|c|c|c|c|c|c|}
\hline & & $\begin{array}{l}\text { Levene's } \\
\text { Test for } \\
\text { Equality of } \\
\text { Variances } \\
\end{array}$ & t-test fo & r Equalit & ty of Me & ans & & & \\
\hline & & \multirow[b]{2}{*}{ Sig. } & \multirow[b]{2}{*}{$\mathrm{T}$} & \multirow[b]{2}{*}{ Df } & \multirow[t]{2}{*}{$\begin{array}{l}\text { Sig. -2) } \\
\text { tailed) }\end{array}$} & \multirow[t]{2}{*}{$\begin{array}{l}\text { Mean } \\
\text { Difference }\end{array}$} & \multirow[t]{2}{*}{$\begin{array}{l}\text { Std. Error } \\
\text { Difference }\end{array}$} & \multicolumn{2}{|c|}{$\begin{array}{l}95 \% \text { Confidence } \\
\text { Interval of the } \\
\text { Difference }\end{array}$} \\
\hline & & & & & & & & Lower & Upper \\
\hline \multirow[t]{2}{*}{ Posttest_Praktik } & $\begin{array}{l}\text { Equal } \\
\text { variances } \\
\text { assumed }\end{array}$ & $6.965 \quad .011$ & 24.271 & 44 & .000 & 3.56362 & .14683 & 3.26771 & 3.85953 \\
\hline & $\begin{array}{l}\text { Equal } \\
\text { variances' } \\
\text { assumed }\end{array}$ & & 23.320 & 32.096 & .000 & 3.56362 & .15281 & 3.25238 & 3.87485 \\
\hline
\end{tabular}


Pada Tabel 7 hasil Posttest ${ }_{\text {praktik }}$ diketahui hasil $\mathrm{F}_{\text {hitung }}$ levene test sebesar 6,965 dengan signifikansi 0,011 . Karena $\mathrm{p}<0,05$, maka kedua populasi tersebut mempunyai variance yang berbeda. Analisis uji bedattest terlihat bahwa nilai $\mathrm{t}_{\text {hitung }}$ di bagian equal assumed adalah 24,271 dengan signifikansi (2tailed) sebesar 0,000. Karena $\mathrm{p}<0,05$, maka $\mathrm{H}_{0}$ ditolak dan $\mathrm{H}_{1}$ diterima yang artinya bahwa ada perbedaan prestasi belajar Fisika antara peserta didik yang diajar dengan menggunakan metode Levels of Inquiry Learning Cycle dengan peserta didik yang diajar dengan menggunakan metode Ceramah.

Berdasarkan hasil uji beda $t$-test ratarata nilai prestasi belajar Fisika pada Posttest $_{\text {soal PG }}$ Posttest $_{\text {soal Ur }}$ dan Posttest praktik $_{\text {da }}$ diantara peserta didik yang diajar dengan menggunakan metode Levels of Inquiry Learning Cycle dan peserta didik yang diajar dengan metode Ceramah secara keseluruhan membuktikan bahwa peserta didik yang diajar dengan menggunakan metode Levels of Inquiry Learning Cycle mempunyai rata-rata prestasi belajar Fisika yang lebih tinggi daripada peserta didik yang diajar dengan metode Ceramah dan memiliki perbedaan yang signifikan. Dengan demikian maka dapat dikatakan bahwa metode Levels of Inquiry Learning Cycle dapat meningkatkan prestasi belajar secara signifikan.

Hasil penelitian ini sejalan dengan hasil penelitian Budiarsih dan Widarti (2004), serta Fibriyanti (2006). Dalam penelitian-penelitian yang telah mereka lakukan sebelumnya menyimpulkan bahwa metode Learning Cycle yang berbasis pada penyelidikan (inkuiri) dapat meningkatkan kualitas proses dan hasil belajar peserta didik secara signifikan. Secara teoritik, hasil penelitian ini mendukung pendapat Carl J. Wenning yang mengembangkan metode Levels of Inquiry Learning Cycle di Ilinois State
University, Physics TeacherEducation Program, USA, dimana metode yang berpusat pada peserta didik ini mampu meningkatkan pemahaman peserta didik pada materi yang peserta didik pelajari dan mampu meningkatkan prestasi belajar Fisika secara signifikan.

Hal yang menyebab metode Levels of Inquiry Learning Cycle dapat meningkatkan prestasi belajar Fisika secara signifikan adalah proses pembelajaran yang bergerak dari hal yang sederhana menuju ke hal yang lebih rumit. Tingkatan Levels of Inquiry yang terdiri dari Discovery Learning, Interactive Demonstration, Inquiry Lesson, Inquiry Lab, dan Hypothetical Inquiry merupakan tingkatan praktik pedagogik yang mengarahkan peserta didik untuk melakukan penyelidikan dari hal yang sederhana menuju hal yang rumit dan tingkatan praktik pedagogik ini sangat membantu peserta didik untuk memahami suatu materi dengan lebih mendalam. Selain itu, tidak hanya Level of Inquiry saja yang sangat berperan dalam meningkatkan prestasi belajar Fisika peserta didik, namun tahapan Learning Cycle dari tahap Observation, Manipulation, Generation, Verification sampai Application yang terdapat pada setiap tingkatan Levels of Inquirymembuat peserta didik mampu memahami sebuah materi dengan pengalaman yang mereka lakukan dan temukan dalam tahapan-tahapan di Learning Cycle. Hal inilah yang mengakibatkan peserta didik yang diajar dengan metode Levels of Inquiry Learning Cycle memiliki prestasi belajar yang lebih tinggi dibandingkan dengan peserta didik yang diajarkan dengan metode Ceramah, karena selain lebih memahami sebuah materi secara teori peserta didik yang diajar dengan metode Levels of Inquiry Learning Cycle juga memiliki keahlian dalam mempraktikkan materi yang mereka pelajari. Terlebih lagi pada penelitian ini materi pembelajaran yang digunakan adalah 
materi rangkaian listrik yang kompetensi dasarnya menuntut peserta didik untuk dapat memahami sebuah teori hukum $\mathrm{Ohm}$ dan mampu mempratikkannya dalam kehidupan sehari-hari. Sehingga hasil penelitian ini menunjukkan bahwa metode Levels of Inquiry Learning Cycle mampu meningkatkan prestasi belajar Fisika secara signifikan.

Namun hasil penelitian ini bertentangan dengan Salis Ates (2005) yang dalam penelitiannya mengungkapkan Learning Cycle yang berbasis inkuiri di Izzet Baysal University, Golkoy-Bolu, Turkey tidak mampu untuk meningkatkan prestasi belajar peserta didik secara signifikan. Penelitian ini juga bertentangan dengan pendapat Ates (2005) bahwa Learning Cycle yang berbasis pada inkuiri tidak dapat meningkatkan prestasi belajar peserta didik pada materi yang bersifat mikroskopis seperti pada materi rangkaian listrik karena materi yang bersifat mikroskopis tidak dapat diamati secara langsung dan dapat mengakibatkan miskonsepsi, namun dalam penelitian ini peneliti mengaplikasikan Levels of Inquiry Learning Cycle pada materi rangkaian listrik dan hasil penelitian ini menunjukkan bahwa Levels of Inquiry Learning Cycle pada materi rangkaian listrik dapat meningkatkan prestasi belajar Fisika peserta didik secara signifikan.

Ketidaksamaan hasil penelitian ini dengan hasil penelitian yang dilakukan olehAtes (2005) dipengaruhi oleh beberapa faktor, diantaranya adalah model Learning Cycle yang berbeda, dan penggunaan subyek yang berbeda. Pada penelitian yang dilakukan oleh Ates, model Learning Cycle yang digunakan adalah model Learning Cycle yang dikembangkan oleh Atkin dan Karlpus yang terdiri dari 3 tahapan yaitu eksplorasi (exploration), pengenalan konsep (concept introduction) dan aplikasi konsep (concept application) sedangkan pada penelitian ini mengunakan model Learning Cycle yang dikembangkan oleh Wenning dan Manzoon A. Kan yang terdiri dari Observation, Manipulation, Generalization, Verification dan Application. Perbedaan model Learning Cycle ini sangat berpengaruh pada proses pemahaman materi, tahapan yang lebih banyak pada model Learning Cycle yang dikembangkan oleh Wenning dan Manzoon A. Kan mengakibatkan peserta didik lebih dapat memahami sebuah materi dengan lebih detail dan mendalam dibandingkan dengan peserta didik yang diajar dengan menggunakan model Learning Cycle yang dikembangkan oleh Atkin dan Karlpus. Selain itu penggunaan subyek penelitian juga mempengaruhi perbedaan hasil penelitian ini dengan hasil penelitian Ates, subyek penelitian Ates adalah mahasiswa dari jurusan Pendidikan Sains di Abant Izzet Baysal University-Turkey sedangkan pada penelitian ini subyek penelitiannya adalah peserta didik di SMK Negeri 1 Ngabang kelas XI jurusan TKR dan TSM. Perbedaan subyek penelitian ini sangat berpengaruh pada keahlian dalam mempraktikkan materi rangkaian listrik, peserta didik dari SMK lebih mempunyai keahlian dalam menggunakan alat-alat praktikum dibandingkan dengan mahasiswa Pendidikan Sains yang merupakan calon guru dan kurang memiliki keahlian dalam menggunakan alat-alat praktikum. Kedua faktor inilah yang mengakibatkan penelitian yang dilakukan oleh Ates (2005) menghasilkan kesimpulan bahwa metode Learning Cycle yang berbasis pada inkuri tidak dapat meningkatkan prestasi belajar Fisika secara signifikan dan pada penelitian ini menghasilkan bahwa metode Levels of Inquiry Learning Cycle mampu meningkatkan prestasi belajar Fisika secara signifikan. 


\section{SIMPULAN}

Berdasarkan hasil penelitian di atas dapat disimpulkan bahwa ada perbedaan yang signifikan antara prestasi belajar Fisika peserta didik yang diajar dengan menggunakan metode pembelajaran Levels of Inquiry Learning Cycle dengan pesertadidik yang diajar menggunakan metode Ceramah. Nilai rata-rata prestasi belajar Fisika peserta didik yang diajar dengan menggunakan metode Levels of Inquiry Learning Cycle lebih baik dari pada peserta didik yang diajar dengan metode Ceramah.

\section{DAFTAR PUSTAKA}

Abdullah, M. 2007. IPA Fisika. Jakarta, Esis.

Anwar, Kasful dan Hendra Harmi. 2010. Perencanaan Sistem Pembelajaran Kurikulum Tingkat Satuan Pendidikan (KTSP). Bandung. ALFABETA.

Arikunto, S. 2006. Prosedur Penelitian: Suatu Pendekatan Praktik. Jakarta. Rhineka Cipta.

Ates, Salih. 2005. The Effects of Learning Cycle on College Students Understanding of DifferentAspects in Resistive DCCircuits. Turkey. Electronic Journal of Science Education, Vol. 9, No. 4.

Baker, R., M., Rudd, R., \& Pameroy, C. 2001. "Relationships between Critical and Creative Thinking," Journal of Southern Agricultural Education Research Volume 5I Number I. [e-journal] http:// www.pubs.tamu.edu/jsaer/pdf/vol51/5100-173.pdf (diakses 10 Januari 2012)

Bentley, M., Ebert, C., \& Ebert, E., S. 2000. The Natural Investigator: A Contructivist Approach to Teaching Elementary and Middle School Science. Balmont, Wadsworth.
Champbell, D. 2000. Mengembangkan Kreativitas. Yogyakarta, Kanisius.

Chrismawati, M. 2009. Model Learning Cycle (Siklus Belajar) Untuk Meningkatkan Keterampilan Berpikir Kritis dan Kemampuan Berpikir Kreatif Peserta didik SMA Pada Pelajaran Fisika. Jakarta, Program Magister PendidikanFakultas Ilmu Pendidikan-UPH.

Darliana. 2007. "Kompetensi Ilmiah dan Kelemahan Pendidikan Sains,".Majalah Ilmu Pengetahuan Alam. vol.VII.[ejournal] http://www.scribd.com/doc/ 2369277/Majalah-IPA-2007. (diakses 4 Januari 2012).

Depdiknas. 2003. Kurikulum 2004 Pedoman Khusus Perkembangan Silabus dan Pengukuran. Jakarta: Depdiknas.

Depdiknas. 2008. Penetapan Kriteria Ketuntasan Minimal (KKM). Jakarta. Departemen Pendidikan NasionalDirektorat Jendral Manajemen Pendidikan Dasar dan Menengah.

Direktorat Pembina SMA. 2010. JUKNIS PENETAPAN KKM DI SMA. Jakarta. Departemen Pendidikan NasionalDirektorat Pembinaan SMA.

Dewey, John. 1913. Interest and effort in education. Boston, New York: Houghton MifflinCo.

Dewey, John. 1916. Democracy and Education: An Introduction to the Philosophy of Education. New York: The Macmillan Company.

Dewey, John. 1939. Experience and Education. New York: The Macmillan Company.

Dewey, John. 1958. Experience and nature. New York: Dover Publications. 
Dewey, John. 1958. Art as experience. New York: Caprocorn Books.

Dewey, John. 1964. John Deweyon education; selected writing. New York: Modern Library.

Dewey, John. 1961. Deweyon education. New York: Bureau of Publications, Teacher College, Columbia University.

Efendi, Ridwan. 2010. Kemampuan Fisika Peserta didik Indonesia dalam TIMSS. (TREND OF INTERNATIONAL ON MATHEMATICS AND SCIENCE STUDY). Jurusan Pendidikan Fisika FPMIPA, Universitas Pendidikan Indonesia. Prosiding Seminar Nasional Fisika 2010.

Eisenkraft, Arthur. 2003. Expending the 5E Model. New York. The Science Teacher (70(6): 56-59).

Fajaroh, F., \& Dasna I Wayan. 2007. Pembelajaran dengan Model Siklus Belajar (Learning Cycle). Diperoleh dari http:// lubisgrafura.wordpress.com/2007/09/20/ pembelajaran-dengan-model siklusbelajar-learning-cycle/; Internet; (diakses 10 Januari 2012).

Fibriyanti, R. 2006. Implikasi Modul Model Siklus Belajar untuk Meningkatkan Kreativitas dan Prestasi Belajar Fisika Peserta didik Kelas VII SMP Laboratorium UM. Diperoleh dari http:// www.infoskripsi.com/Research/ Implementasi-Modul-Model-SiklusBelajar-Untuk-MeningkatkanKreativitas-Dan-Prestasi-Belajar-FisikaS.html; Internet; (diakses 12 Januari 2012).

Filsamine, D., K.2008. Menguak Rahasia Berpikir Kritis dan Kreatif.Jakarta, Pretasi Pustaka.
Grounlund, N.E. 1985. Measurement and evaluationin testing (5th Ed.)New York: Macmillan Publising Co, Inc

Hanuscin, D., L. \& Lee, M., H. 2007. Using a Learning Cycle Approach to Teaching the Learning Cycle to Presevice Elementary Teacher. Diperoleh dari http://web.missoure.edu/-hanuscind/ aste20075E.pdf; Internet; (diakses 29 Desember 2011).

Haryati, Mimin. 2007. Model \& Teknik Pengukuran Pada Tingkat Satuan Pendidikan. Jakarta. Gaung Persada Press.

Herdian. 2010. Model Pembelajaran Inkuiri. Diperoleh dari http://herdy07. wordpress. com/2010/05/27/model-pembelajaraninkuiri/; Internet; (diakses 13 Februari 2012).

Holyak, K.,J., \& Morrison, R.,G. 2005. The Cambridge Handbook of Thinking and Reasoning. New York, Cambridge.

Hook, S. 1969. "John Dewey: His Philosophy of Education and Its Critics". New York: Random House, inc.

Indrawati. 1999. Model-Model Pembelajaran IPA. Bandung, Pusat Pengembangan Penataran Guru Ilmu Pengetahuan Alam, Departemen Pendidikan dan Kebudayaan Direktorat Jenderal Pendidikan Dasar dan Menengah.

Iryanti, Puji. 2004. Pengukuran Unjuk Kerja. Yogyakarta.Departemen Pendidikan Nasional.

Kanginan, M. 2007. Fisika untuk SMA Kelas $X$ Semester 2. Bandung, Erlangga.

Kilpatrick, W. H. 1951. Philosophyof Education. New York: The Macmillan Company.

Kurikulum Tingkat Satuan Pendidikan. Diperolehdarihttp://id.wikipedia.org/wiki/ 
Kurikulum_Tingkat_Satuan_Pendidikan. (Diakses 17 Mei 2012).

Munaf. 2001. Evaluasi Pendidikan Fisika. Bandung: UPI.

Munandar Utami, S.,C. 1999. Kreativitas \& Keberbakatan: Strategi Mewujudkan Potensi Kreatif \& Bakat. Jakarta, Gramedia.

Nasution, M.,A. 2007. Metode Research: Penelitian Ilmiah. Jakarta. Bumi Aksara.

Nurinasari, B. 2004.Sistem Pembelajaran KBK Terhadap Motivasi Belajar Para Peserta Didik pada Bidang Studi Fisika. Diperoleh dari http://researchengines.com/art05-57.html; Internet; (diakses 9 Januari 2012)

OECD PISA.2009. OECD Progranmme for International Student Assessment (PISA). Diperoleh dari http://www. pisa. oecd. org/pages/0,3417,en 32252351 32235731_1_1_1_1_1.00.html: Internet; (diakses 18 Mei 2012).

Perkembangan Kurikulum Pendidikan di Indonesia. Diperoleh dari http:// www.infodiknas.com/027 pengembangan-kurikulum-pendidikandiindonesia/; Internet; (diakses $17 \mathrm{Mei}$ 2012).

PISA. 2009. Rangking by Mean Score for Reading, Mathematics and Science. Diperoleh dari http://www.straitstimes. com/STI/STIMEDIA/pdf/20101207/ PISA2009MOEFinal.pdf; Internet; (diakses 17 Mei 2012).

Powell James. 1995. An integrating interface to data. The Graduate School.University of Salford.Salford.

Puspendik. 2011. Survei Internasional TIMSS. Diperoleh darihttp://litbang. kemdikbud. go.id/detail.php?id=214; Internet; (diakses 18 Mei 2012).
Sanjaya Wina. 2006. Strategi Pembelajaran. Jakarta. Kencana Prenada Media Grup.

Sarwono Jonathan. 2010. Belajar Statistik Mudah dan Cepat-PASW Statistics 18. Yogyakarta. ANDI Yogyakarta.

Sawyer, K. R. 2006.Explain Creativity: The Science of Human Innovation. New York, Oxford.

Shook, J. R. 2000. Truth and Pragmatic theory of Learning. Encyclopedia of Philosophy of Education. Diperoleh dari http://vusst.hr/ENCYCLOPEDIA; Internet; (diakses 20 Mei 2012).

Sriyono. 2004. Pengembangan sistem pengukuran berbasis kompetensi peserta diklatSekolah Menengah Kejuruan. Proceding: Rekayasa Sistem Pengukuran dalam Rangka Meningkatkan Kualitas Pendidikan. Yogyakarta: HEPI.

Sugiyono. 2008. Metode Penelitian: Pendekatan Kuantitatif, Kualitatif dan $R \& D$. Bandung. ALFABETA.

Tarmidi.2006. Iklim Kelas dan Prestasi Belajar. Medan, Program Studi Psikologi Fakultas Kedokteran Universitas Sumatera Utara.

TimDosen Administrasi Pendidikan Universitas Pendidikan Indonesia. 2009. Manajemen Pendidikan. Bandung. ALFABETA.

Triwijayanti, Nobita. 2011. Spektrum Inkuiri Pada Materi Hukum Hooke. Salatiga. Program Pendidikan Fisika-Fakultas Sains dan Matematika-UKSW.

Wenning, C.J. 2005a. Levels of Inquiry: Hierarchies of Pedagogical Practices and Inquiry Processes. Journal of Physics Teacher Education Online, 2(3), 3-11.

Wenning, C.J. 2006. A framework for teaching the nature of science. Journal of Physics Teacher Education Online, 3(3), 3-10. 
Wenning, C.J. \& Khan, M.A. 2011. The Levels of Inquiry Model of Science Teaching. Journal of Pysics Teacher Education Online, 6(2), 9-16.

Winkel, W.,S. 1991. Psikologi Pengajaran. Jakarta. Gramedia.

Winkel, W.,S. 2007. Psikologi Pengajaran. Yogyakarta. MediaAbadi.
Widoyoko, S. 2012. Evaluasi Program Pembelajaran. Yogyakarta, Pustaka Palajar.

Yamin, Martinis. 2005. Strategi Pembelajaran Berbasis Kompetensi. Cipayung.Gaung Persada Press.

Zainul, Asmawi. 2001. Alternative Assesment. Jakarta: PAU-PPAIUniversitas Terbuka. 